\title{
Description of the male of fossil Calomicrus eocenicus Bukejs et Bezděk (Coleoptera: Chrysomelidae: Galerucinae) from Eocene Baltic amber using $X$-ray microtomography
}

\author{
Andris Bukejs ${ }^{1}$, Jan Bezděk ${ }^{2}$, Vitalii I. Alekseev ${ }^{3,4}$, Kristaps Kairišs ${ }^{1}$, and Ryan C. McKellar ${ }^{5,6,7}$ \\ ${ }^{1}$ Institute of Life Sciences and Technologies, Daugavpils University, Vienības 13, Daugavpils, 5401, Latvia \\ ${ }^{2}$ Department of Zoology, Mendel University, Zemědělská 1, 61300 Brno, Czech Republic \\ ${ }^{3}$ Shirshov Institute of Oceanology, Russian Academy of Sciences, Nahimovskiy prospekt 36, Moscow 117997, Russia \\ ${ }^{4}$ Kaliningrad Regional Amber Museum, Marshal Vasilevskii square 1, Kaliningrad 236016, Russia \\ ${ }^{5}$ Royal Saskatchewan Museum, 2445 Albert St., Regina, SK, S4P 4W7, Canada \\ ${ }^{6}$ Biology Department, University of Regina, Regina, SK, S4S 0A2, Canada \\ ${ }^{7}$ Department of Ecology \& Evolutionary Biology, University of Kansas, Lawrence, Kansas 66045, USA
}

Correspondence: Andris Bukejs (carabidae@inbox.lv)

Received: 18 March 2020 - Revised: 23 April 2020 - Accepted: 1 May 2020 - Published: 11 June 2020

\begin{abstract}
A male representative of the extinct species Calomicrus eocenicus Bukejs et Bezděk, 2014 (Chrysomelidae: Galerucinae) is found and described for the first time from Eocene Baltic amber using X-ray microtomography. The aedeagus is well preserved within the body cavity of the specimen, and it is illustrated in detail. This fossil species exhibits distinct sexual dimorphism: the male has a smaller total body size, as well as a copula-adapted modification in abdominal ventrite 5 (apical margin deeply trilobed, with round medial fovea present); meanwhile the female is larger in body size and has a simple abdominal ventrite 5 (without fovea, non-incised and widely rounded apically). Similar sexually dimorphic characters are typical for extant members of the tribe Luperini, and this report is the first time that they are described in an Eocene species. The known sexually dimorphic characters present in Coleoptera within Eocene Baltic amber are briefly discussed.
\end{abstract}

\section{Introduction}

Records of Galerucinae sensu stricto (excluding Alticini) from fossil resins are scarce. Until now only four species have been described: Leptonesiotes virkkii Santiago-Blay, Poinar et Craig, 1996 from middle Miocene Dominican amber (20.43-13.65 Ma) (Santiago-Blay et al., 1996);
Calomicrus eocenicus Bukejs et Bezděk, 2014 from middle Eocene Baltic amber (Bartonian, 41.2-37.8 Ma) (Bukejs and Bezděk, 2014); Calomicroides danicus Nadein, 2015 from upper Eocene Danish (Scandinavian) amber (37.233.9 Ma) (Nadein et al., 2015); and Taimyraltica calcarata Nadein, 2017 from Upper Cretaceous Taimyr amber (85.884.9 Ma) (Nadein and Perkovsky, 2018). Additionally, members of Galerucella Crotch, 1837; Luperus Geoffroy, 1762; and Monolepta Chevrolat, 1836 have been reported from Baltic amber without detailed descriptions (Hope, 1836; Klebs, 1910; Bachofen-Echt, 1949; Hieke and Pietrzeniuk, 1984; Spahr, 1981).

Calomicrus eocenicus was originally described based on a single female specimen. Unfortunately, the holotype was lost during postal shipment. In the current paper, the male of $C$. eocenicus from Baltic amber is described. The male genitalia are examined and illustrated using X-ray microtomography. The external sexually dimorphic characters are described, and the original species concept (based on the female holotype only) is revised. Finally, the available data on sexual dimorphism in fossil Coleoptera from Eocene Baltic amber are briefly discussed. 


\section{Geological setting}

Baltic amber originally occurs within the "blaue Erde" ("Blue Earth") horizon, which can be found throughout the Baltic Sea coastal area in Europe (Kaliningrad region, Russia; Poland; Denmark; Sweden; Germany; and Lithuania) (Engel, 2001). Although most estimates of the age of Baltic amber have suggested that it is derived from the early part of the middle Eocene (Lutetian, 47.8-41.2 Ma) based largely on K-Ar dating (Ritzkowski, 1997), palynological biostratigraphy of the specific region where the sample originated suggests a younger, late Eocene (Priabonian, 37.8-33.9 Ma) age (Aleksandrova and Zaporozhets, 2008). An intermediate, middle Eocene (mostly Bartonian, 41.2-37.8 Ma) age was recently proposed for the extinct central European resinproducing forests according to the stratigraphy of the Sambian amber deposits (Bukejs et al., 2019). Following classical views (e.g. Andrée, 1951; Poinar, 1992; Turkin, 1997), Baltic amber is thought to have been produced by Pinus succinifera (Göppert) Conwentz. Pinaceae along with different coniferous (Sadowski et al., 2017) and deciduous (primarily fagacean) trees, dominated the mixed forest cover of northern and central Europe in the warm-temperate, humid conditions of the Eocene. More recent research on the chemical composition of Baltic amber has also hypothesized that trees within the families Araucariaceae or Sciadopityaceae might be candidates for the production of this amber deposit (Wolfe et al., 2009; Lambert et al., 2014); however, the final chemical composition of amber can be influenced by long-term diagenetic processes, leaving the source tree for the deposit open to debate.

\section{Material and methods}

The material examined is deposited in the Palaeontology Collection of the Royal Saskatchewan Museum (Regina, Saskatchewan, Canada) (RSKM specimen number prefix).

Observations of the studied beetle specimen were made using a Nikon SMZ745T stereomicroscope. Photographs were taken using a Visionary Digital imaging system, consisting of a Canon EOS 5D camera with a Canon MP-E $65 \mathrm{~mm}$ macrophotography lens, attached to an automated camera lift with studio flash lighting. Extended depth of field at high magnifications was achieved by combining multiple images from a range of focal planes using Helicon Focus 6.8.0 software, and the resulting images were edited to create figures using Adobe Photoshop CS5.

The X-ray micro-CT observations of specimen RSKM_P3300.139 were conducted at Daugavpils University, Daugavpils, Latvia (DU), using a Zeiss Xradia 510 Versa system. Scans were performed with a polychromatic X-ray beam at an energy of $40 \mathrm{kV}$ and power of $3 \mathrm{~W}$. Sample-to-detector distance was set to $17.5 \mathrm{~mm}$, and source-to-sample distance was $47.7 \mathrm{~mm}$. Tomographic slices were generated from 3001 rotational steps through a $360^{\circ}$ rotation, using a $4 \times$ objective, and the exposure time during each projection was set to $5 \mathrm{~s}$. Acquired images were binned $(2 \times 2 \times 2)$, giving a voxel size of $4.87 \mu \mathrm{m}$. Images were imported into the Dragonfly PRO (version 4.1) software platform for interactive segmentation and $3 \mathrm{D}$ visualization.

\section{Systematic palaeontology}

Family Chrysomelidae Latreille, 1802

Subfamily Galerucinae Latreille, 1802

Tribe Luperini Gistel, 1848

Subtribe Luperina Gistel, 1848

Genus Calomicrus Dillwyn, 1829

Calomicrus eocenicus Bukejs et Bezděk, 2014

Figs. 1-4

\section{Material examined}

Collection number RSKM_P3300.139, male. A complete beetle is included in an elongate, transparent, yellow amber piece with dimensions of $41 \mathrm{~mm} \times 19 \mathrm{~mm} \times 8 \mathrm{~mm}$, and preserved without supplementary fixation. Syninclusions: one specimen of Hymenoptera, a few stellate Fagaceae trichomes, numerous small detritus particles and gas vesicles.

\section{Strata}

Baltic amber from Eocene amber-bearing Blue Earth layers (a primarily Bartonian age is interpreted for the extinct central European resin-producing forests, according to Bukejs et al., 2019).

\section{Locality}

Yantarny settlement (formerly Palmnicken), Sambian (Samland) Peninsula, Kaliningrad region, Russia.

\section{Note}

Specimen RSKM_P3300.139 is morphologically similar to the female holotype of Calomicrus eocenicus and is identified as male, showing sexually dimorphic characters of abdominal ventrite 5 and a distinctly smaller body size (see Discussion).

\section{Description of male}

Measurements: total body length $3.5 \mathrm{~mm}$; pronotum length $0.75 \mathrm{~mm}$, pronotum maximum width $1.0 \mathrm{~mm}$; elytra length $2.7 \mathrm{~mm}$, elytra maximum width $1.9 \mathrm{~mm}$. 

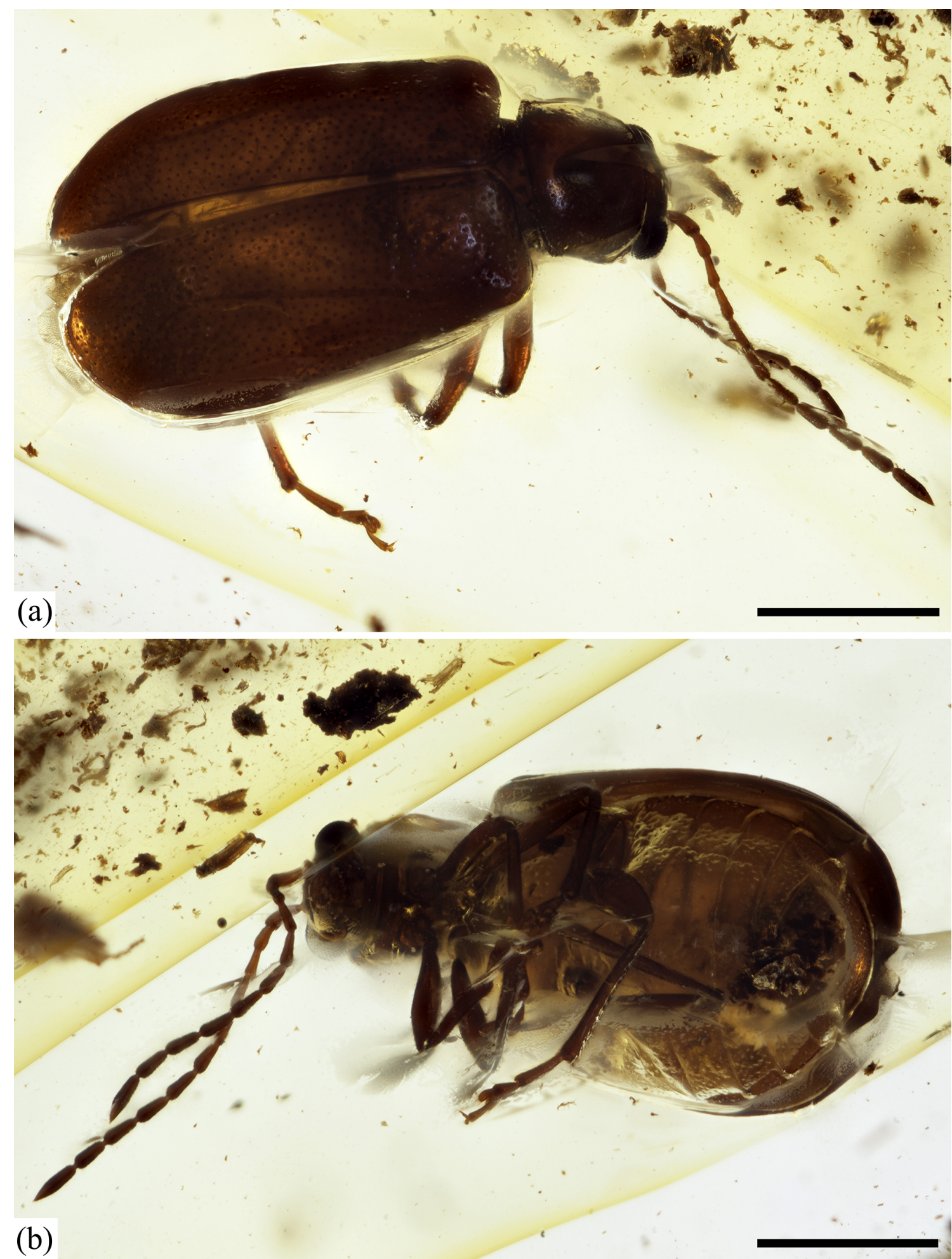

Figure 1. Calomicrus eocenicus Bukejs et Bezděk, RSKM_P3300.139, photomicrographs, habitus: (a) dorsal view; (b) ventral view. Scale bars $=1.0 \mathrm{~mm}$. 


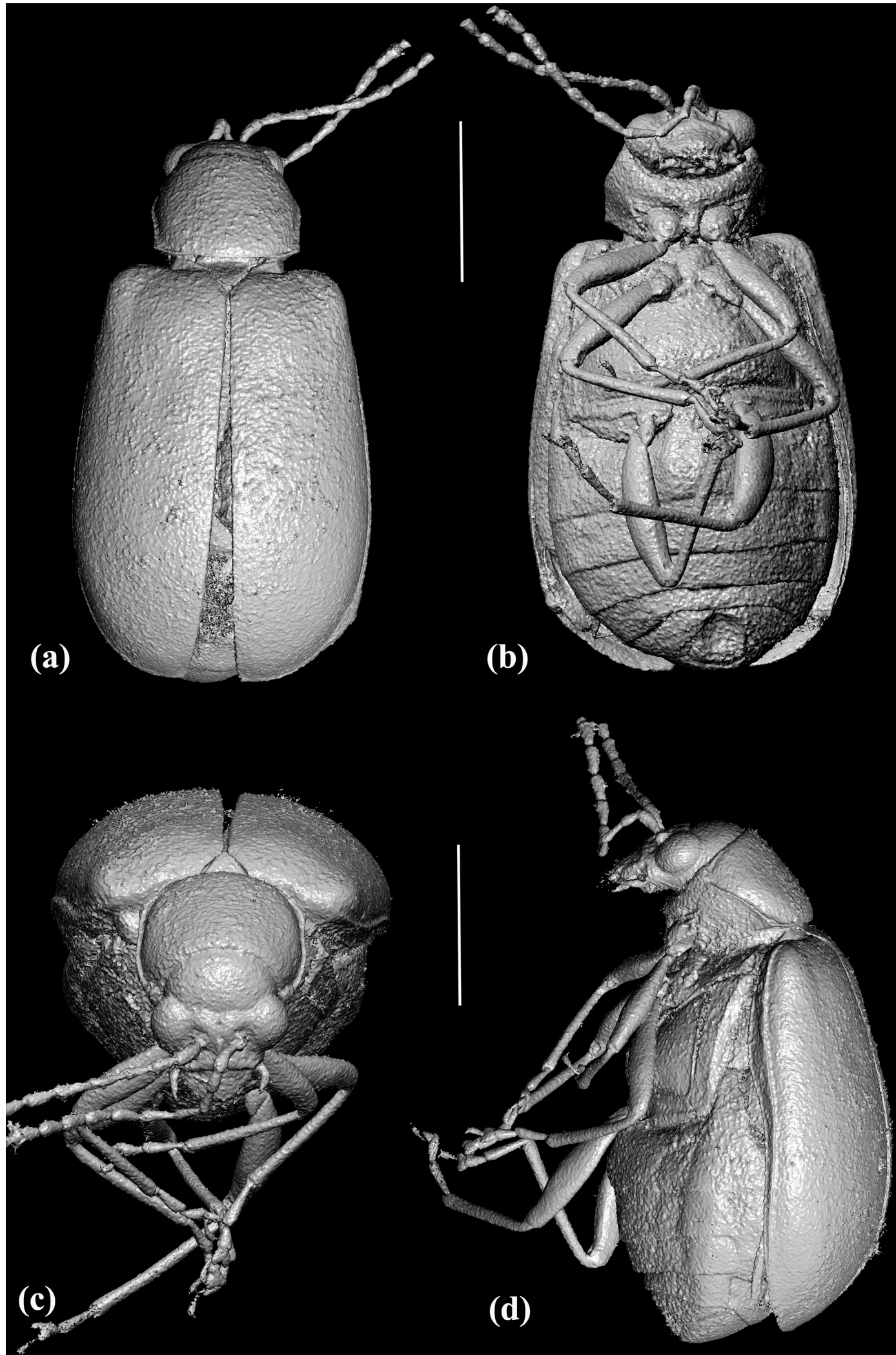

Figure 2. Calomicrus eocenicus Bukejs et Bezděk, RSKM_P3300.139, X-ray micro-CT renderings, habitus: (a) dorsal view; (b) ventral view; (c) frontal view; (d) left lateral view. Scale bars $=1.0 \mathrm{~mm}$. 


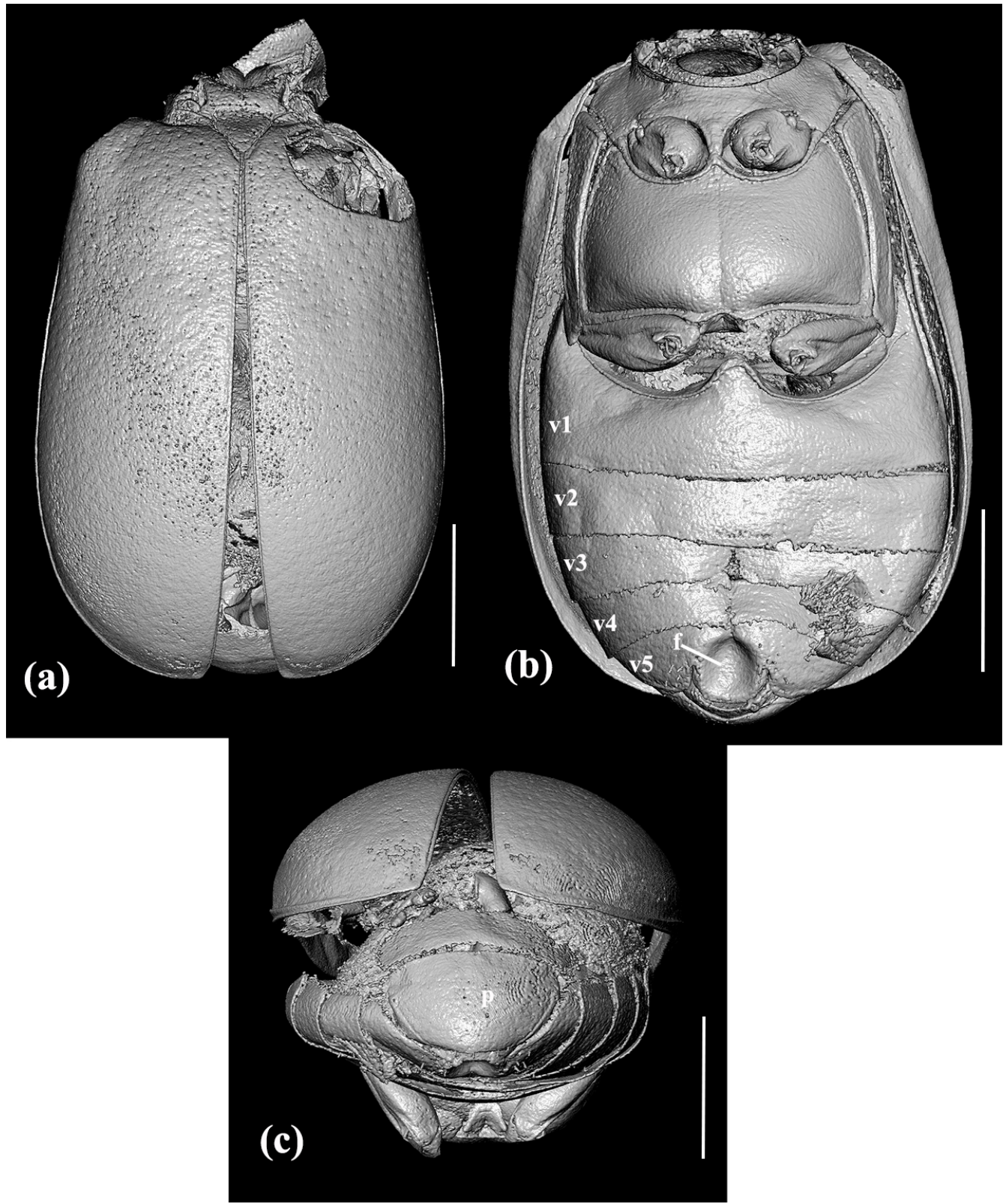

Figure 3. Calomicrus eocenicus Bukejs et Bezděk, RSKM_P3300.139, X-ray micro-CT renderings: (a) elytra, dorsal view, with clipping planes exposing details beneath pronotum and right elytron; (b) pterothorax without legs, ventral view; (c) habitus without legs, caudal view. Scale bars $=0.5 \mathrm{~mm}$. Abbreviations: $\mathrm{f}-$ fovea; $\mathrm{p}$ - pygidium; v1-v5 - abdominal ventrites 1-5 respectively.

Body elongate, slender, slightly convex dorsally and ventrally; reddish-brown as preserved, shiny, with weak metallic lustre; glabrous dorsally, with very fine, short, recumbent setation ventrally (distinctly visible on pygidium and abdomen).

Head hypognathous, relatively small, without distinct punctures; head together with eyes slightly wider than anterior margin of pronotum; vertex slightly convex. Compound eyes directed laterad, oval in outline, moderately large, prominent, entire, with distinct facets; vertical diam- eter $1.3 \times$ transverse diameter. Distance between eyes equal to about $1.4 \times$ transverse diameter of one eye. Antennal calli wide and elongate, slightly oblique, apparently contiguous; supracallinal sulcus distinct. Frontal ridge narrow, and sharp. Clypeus strongly transverse, with anterior margin concave. Labrum transverse, about $1.4 \times$ length of clypeus; anterior margin almost straight. Antennae filiform, slender, with 11 antennomeres; covered with fine, pale, semierect setae; antennae rather long, extending to reach posterior one-third of elytral length; antennomeres cylindrical, elongate; scape 


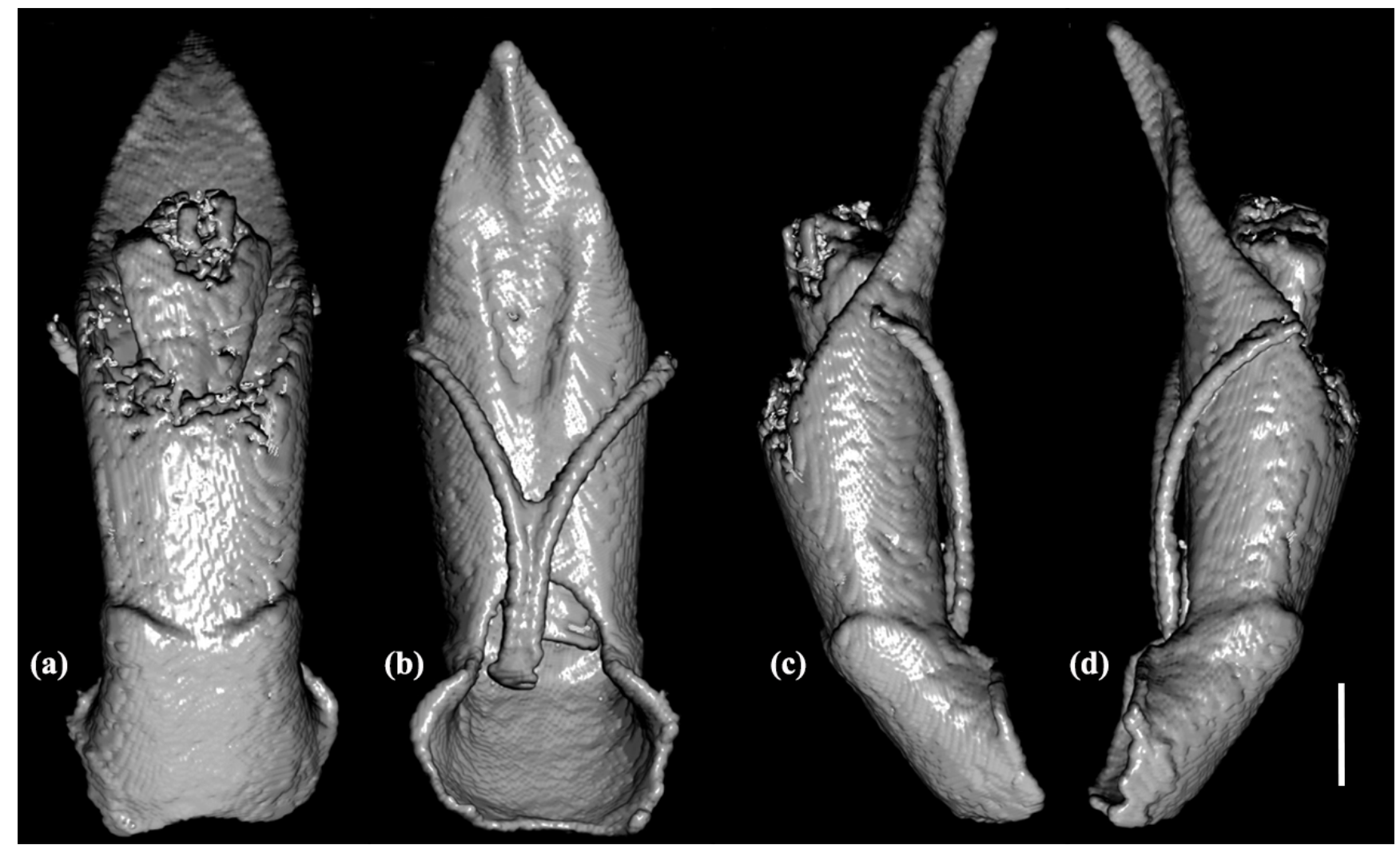

Figure 4. Calomicrus eocenicus Bukejs et Bezděk, RSKM_P3300.139, X-ray micro-CT renderings, aedeagus: (a) dorsal view; (b) ventral view; (c) right lateral view; (d) left lateral view. Scale bars $=0.1 \mathrm{~mm}$.

$1.4 \times$ times as wide as antennomere 3 ; pedicle shortest, about $0.9 \times$ as long as antennomere 3 ; antennomeres $3-10$ slightly dilated apically; antennomere 11 nearly spindle-shaped, with pointed apex, $3.3 \times$ as long as wide. Relative length ratios of antennomeres $1-11$ equal to $9: 6: 7: 8: 8: 8: 8: 8: 9: 8: 11$. Antennal insertion positioned posterior to anterior border of eyes. Distance between antennal sockets nearly equal to diameter of one socket.

Prothorax. Pronotum transverse, about $1.33 \times$ as wide as long, widest in anterior one-third of pronotal length, and slightly narrowed both anteriad and posteriad. Lateral margins widely rounded, with pronounced bordering; posterior margin slightly convex, with narrow bordering; anterior margin straight in dorsal view, arcuate in frontal view. Pronotal disc impunctate; lateral regions with sparse, very fine and effaced punctation (distinctly smaller than elytral punctures). Posterior angles distinct, nearly orthogonal; anterior angles indistinct, not protruding laterally. Anterior and posterior setiferous pores bearing long setae. Prohypomera and prosternum without distinct punctation; procoxal cavities open posteriorly; prosternal process sharp, very narrow, about $0.1 \times$ as wide as transverse diameter of procoxa.

Pterothorax. Scutellar shield small, triangular, impunctate, and glabrous. Elytra weakly convex, subparallel-sided, slightly narrowed posteriad, and widest in posterior one- third of elytral length; elytral anterior margin distinctly wider than pronotal posterior margin; covered with small, irregular punctures, in moderately dense arrangement, with distance between punctures equal to 1-3x diameter of one puncture. Humeral calli well developed, prominent. Elytral apices rounded. Metathoracic wings present, but details not observable in micro-CT scan data. Epipleura wide, gradually narrowed posteriorly, not reaching elytral apex, and covered with fine punctures. Metaventrite moderately convex, with distinct median line; covered with rugosity and very fine punctures. Metepisternum with rugosity and fine punctures, about $3.7 \times$ as long as wide; anterior and posterior margins oblique, lateral margins concave.

Legs slender, moderately long; covered with short, semierect setae. Procoxae widely oval and slightly transverse, $1.3 \times$ as wide as long, very narrowly separated; mesocoxae widely oval, narrowly separated by about $0.2-0.3 \times$ transverse diameter of mesocoxa; metacoxae narrowly elongate, transverse, moderately separated by about $0.5 \times$ transverse diameter of metacoxa. Femora slightly flattened and slightly dilated medially; metafemora and metatibiae equal in length; metafemora about $3 \times$ as long as wide. Tibiae almost straight, parallel-sided, without spines apically; metatibiae about $11 \times$ as long as wide. Tarsi long; metatarsus about $0.7 \times$ as long as metatibia; all tarsomeres 3 deeply bilobed; pro- 
tarsomeres 1-3 slightly dilated apically, with protarsomere 1 about $0.3 \times$ as wide as long, protarsomere 2 about $0.6 \times$ as wide as long, and protarsomere 3 about $1.1 \times$ as wide as long. Relative length ratios of metatarsomeres $1-4$ equal to $12: 5: 5: 7$. Claws thin, with large denticle basally.

Abdomen with five visible ventrites, densely covered with fine punctures. Ventrite 5 with deep, oval fovea medially; posterior margin trilobed (median lobe moderately narrow with rounded apical margin; incisions short). Relative length ratios of ventrites $1-5$ equal to $18: 10: 5: 6: 12$ (measured medially). Pygidium evenly covered with dense, fine punctures.

Aedeagus (Fig. 4) lanceolate, with sharp triangular apex; in lateral view, aedeagus moderately curved, with apical onethird of length thin, and middle part wide; in ventral view, aedeagus with wide, $\mathrm{V}$-shaped, longitudinal furrow in middle part of length, and with longitudinal, medial carina in apical one-fifth of length. Tegmen Y-shaped.

\section{Discussion}

Sexual dimorphism can be an important feature useful in morphological, taxonomic, and phylogenetic studies. Sexual dimorphism consists of both primary and secondary sexual characteristics. The former include the features of the reproductive system (e.g. chromosomes, gonads, and genitalia), while the latter are very diverse and include different external (morphological) and internal (e.g. hormonal) adaptations. Secondary characteristics develop within each sex to facilitate ecological (e.g. feeding), behavioural (e.g. copulation, migration, offspring care) and other differences between specimens belonging to each sex. Features such as wing development, antennal length ratios, the form and size of sense organs or mandibles, tarsal setation and dilatation, horns, teeth, and different structural modifications of the exoskeleton (like furrows, foveae, projections on pronotum and elytra etc.), total body size, and colour variability are among the many well-known sexually dimorphic characters in Recent Coleoptera (Arrow, 1951; Crowson, 1981; Klausnitzer, 2002; Gullan and Cranston, 2014).

Sexual dimorphism in extant members of the tribe Luperini (Coleoptera: Galerucinae) is characterized as follows: males always have a trilobed abdominal ventrite 5 , often with the middle lobe impressed; meanwhile, abdominal ventrite 5 is always simple and entire in females; often the males have slightly wider first tarsomeres and longer antennae (e.g. Wagner, 2003; Bezděk, 2015). Rarely the males of some luperin genera have also modified head, elytra or legs (Mohamedsaid and Furth, 2011; Prado, 2013). However, the sexually dimorphic characters present on the abdomens of fossil representatives of Luperini have never been described. The description of Diabrotica exesa Wickham, 1911 is brief, and sexually dimorphic characters are not mentioned (Wickham, 1911). The holotype of Leptonesiotes virkkii Santiago-Blay,
Poinar et Craig, 1996 is probably male, based on the structure of middle tibiae, but the terminal part of the abdomen is missing within this specimen (Santiago-Blay et al., 1996). The abdomen is also not visible in the holotype of Calomicroides danicus Nadein, 2015 (Nadein et al., 2015).

Calomicrus eocenicus was originally described from a single female (Bukejs and Bezděk, 2014), without any known male counterparts. The male described herein is morphologically similar to the known female. However, sexual dimorphism in this fossil species is distinct: the male has an abdominal ventrite 5 with a trilobed apical margin and with deep, round fovea medially, as well as having a smaller total body size; in the female, abdominal ventrite 5 is without fovea, and widely rounded apically, without incisions, while the total body size is significantly larger.

In general, amber specimens differ from compression fossils, where the sex of specimens is rarely determinable, and reports of sexually dimorphic characters are the exception, rather than the rule. Consequently, three-dimensionally preserved inclusions in fossil resins have the capacity to provide unique data on sexual dimorphism in extinct lineages. Sexual dimorphism in fossil beetles has usually been documented as an incidental observation in taxonomic papers (e.g. Lyubarsky and Perkovsky, 2015; Jiang et al., 2019). It has only received more extensive coverage in a few papers focused on groups such as fossil silvanid beetles like Protoliota antennatus Liu, Ślipiński, Wang et Pang, 2019, from Cretaceous Burmese amber (Cai and Huang, 2019). Both the larger synthetic work and the taxonomic papers on amber inclusions have demonstrated that the antiquity of sexually dimorphic characters in Coleoptera can be traced back to the Cretaceous.

There are several characteristics that can be used for sex determination in fossil species within different beetle groups known from Baltic amber, and these appear to have been stable since at least the Eocene. Dimorphic characteristics include:

- modification of abdominal ventrites: shape of the last abdominal segments in Cantharidae (e.g. Kuśka and Kupryjanowicz, 2005; Fanti and Sontag, 2019 among others), and in Staphylinidae (Bogri et al., 2018); ventrite 1 with median, oval plaque in Monotomidae (Bukejs and Alekseev, 2015a);

- modification of antennomeres in Ripiphorinae (Batelka et al., 2020);

- pronotal shape in Cerambycidae (Vitali, 2006);

- elytral shape in Staphylinidae (Shavrin and Yamamoto, 2019);

- relative lengths of antennae in Cerambycidae (Vitali, 2018) and in Cantharidae (Parisi and Fanti, 2019);

- lateral pronotal lobes in Cantharidae (e.g. Parisi and Fanti, 2019); 
- shape of protarsi and ventral surface of protarsomeres in Carabidae (Gamboa and Ortuño, 2015, 2018; Schmidt, 2015), Chrysomelidae (Bukejs and Konstantinov, 2013), Dytiscidae (Balke et al., 2010), and Melandryidae (Bukejs and Alekseev, 2015b);

- exposed distal parts of male and female genitalia in Aderidae (Alekseev and Grzymala, 2015), Anthicidae (Telnov and Bukejs, 2019), Cantharidae (Kazantsev, 2013), Chrysomelidae (Bukejs and Chamorro, 2015; Bukejs et al., 2015, 2016), Cupedidae (Kirejtshuk, 2005), Ischaliidae (Alekseev and Bukejs, 2017), Lycidae (Kazantsev, 2019), Melandryidae (Alekseev, 2014), Pyrochroidae (Bukejs et al., 2019), Scirtidae (Heuss, 2008; Klausnitzer, 2012), Staphylinidae (Jałoszyński et al., 2018; Brunke et al., 2019; Shavrin and Yamamoto, 2019), Tenebrionidae (Nabozhenko et al., 2019a, b; Telnov et al., 2019; Alekseev et al., 2020a), Zopheridae (Alekseev and Bukejs, 2016) and other groups.

Recent technological advances have allowed researchers to identify the sex of specimens with greater confidence and expand their study of features with significance to sex determination in amber inclusions. X-ray microtomography data obtained from lab-based machines or synchrotron beamlines have allowed sex determination in fossils without visibly exposed genitalia. The optically hidden, internal genitalia have been successfully studied in fossil species of Carabidae (Schmidt et al., 2016, 2017, 2019; Schmidt and Michalik, 2017), Latridiidae (Reike et al., 2017), Leiodidae (Perreau and Tafforeau, 2011; Perreau, 2012; Perreau and Perkovsky, 2014), Merophysiidae (Reike et al., 2020), Mycetophagidae (Alekseev et al., 2020b), Tenebrionidae (Nabozhenko et al., 2020), and other coleopteran families. To date, the sexual dimorphism that has been discovered in Eocene Baltic amber beetles can be characterized as "evolutionarily stable" and limited to characters known in present-day relatives: no new sexually dimorphic characters have been discovered in Eocene fossils. The continued search and accurate study of the Baltic amber beetle assemblage may possibly yield future discoveries in this respect, enabling us to provide further details on the morphology of fossil beetles and the range of variation present within individual taxa.

Data availability. Volume renderings of X-ray microtomography of the habitus, pterothorax and aedeagus of male Calomicrus eocenicus Bukejs et Bezděk, RSKM_P3300.139 are available as a Video supplements.

Video supplement. X-ray micro-CT volume renderings of the habitus, pterothorax, and aedeagus of the male Calomicrus eocenicus Bukejs et Bezděk, RSKM_P3300.139. The videos are available at https://doi.org/10.5446/45963 (Bukejs and Kairišs, 2020a), https: //doi.org/10.5446/45964 (Bukejs and Kairišs, 2020b) and https: //doi.org/10.5446/45965 (Bukejs and Kairišs, 2020c).
Author contributions. $\mathrm{AB}$ designed the study. AB and JB identified the specimen and performed systematic placement. $\mathrm{AB}$ prepared specimen description and plates. KK performed $\mu \mathrm{CT}$ measurements, reconstructed $\mu \mathrm{CT}$ data and created volume renderings and 3D models. VIA prepared the geological background and suggested ideas for discussion. VIA, AB and JB drafted the discussion. RCM located the specimen and prepared photomicrographs and plates. All authors drafted the manuscript and contributed to the writing and discussion.

Competing interests. The authors declare that they have no conflict of interest.

Acknowledgements. The authors are grateful to José Miguel Vela (Instituto Andaluz de Investigación y Formación Agraria y Pesquera (IFAPA), Málaga, Spain) and Shuhei Yamamoto (Field Museum of Natural History, Integrative Research Center, Chicago, USA) for their helpful comments and corrections to an earlier version of this manuscript. The study of Vitalii I. Alekseev was done with the support of the state assignment of IO RAS (theme no. 0149-20190013).

Financial support. This research has been supported by the IO RAS (grant no. 0149-2019-0013).

Review statement. This paper was edited by Torsten Scheyer and reviewed by José Miguel Vela and Shuhei Yamamoto.

\section{References}

Aleksandrova, G. N. and Zaporozhets, N. I.: Palinological characteristic of the Upper Cretaceous and Paleogene sediments of the western part of the Sambian peninsula (the Kaliningrad region). Paper 2, Stratigraphy, Geological correlation, 16, 75-86, 2008.

Alekseev V. I.: New taxa of Baltic amber false darkling beetles (Coleoptera: Melandryidae), Baltic Journal of Coleopterology, 14, 79-96, 2014.

Alekseev, V. I. and Bukejs, A.: New Zopheridae (Coleoptera: Tenebrionoidea) from Baltic amber, Zootaxa, 4178, 409-427, https://doi.org/10.11646/zootaxa.4178.3.6, 2016.

Alekseev, V. I. and Bukejs, A.: New fossil taxa of Ischalia Pascoe (Coleoptera: Ischaliidae) from Eocene Baltic amber, Zootaxa, 4323, 229-238, https://doi.org/10.11646/zootaxa.4323.2.6, 2017.

Alekseev, V. I. and Grzymala, T. L.: New Aderidae (Coleoptera: Tenebrionoidea) from Baltic and Bitterfeld amber, Zootaxa, 3956, 239-257, https://doi.org/10.11646/zootaxa.3956.2.5, 2015.

Alekseev, V. I., Bukejs, A., and Sontag, E.: A new fossil species of Bolitophagini (Coleoptera: Tenebrionidae) suggests the genus Eledonoprius Reitter is persistent in the Western Palaearctic since Tertiary, Zootaxa, 4750, 418-424, https://doi.org/10.11646/zootaxa.4750.3.7, 2020a. 
Alekseev, V. I., Kupryjanowicz, J., Kairišs, K., and Bukejs, A.: The first described fossil species of Litargus Erichson (Coleoptera: Mycetophagidae) from Eocene Baltic amber examined with X-ray microtomography, and new records of Crowsonium succinium Abdullah, 1964, Zootaxa, 4768, 405-414, https://doi.org/10.11646/zootaxa.4768.3.7, 2020b.

Andrée, K.: Der Bernstein. Das Bernsteinland und sein Leben. Stuttgart, Kosmos, Francksche Verhandlung, 1951.

Arrow, G. J.: Horned beetles. A study of the fantastic in nature, W. Junk, The Hague, 1951.

Bachofen-Echt, A.: Der Bernstein und seine Einschlüsse, Springer, Wien, 1949.

Balke, M., Beigel, A., and Hendrich, L.: Hydroporus carstengroehni sp. n. und zwei unbestimmte Hydroporinae aus dem baltischen Bernstein (Dytiscidae: Hydroporinae), Nachrichtenblatt der Bayerischen Entomologen, 59, 2-9, 2010.

Batelka, J., Perkovsky, E. E., and Prokop, J.: Diversity of Eocene Ripiphoridae with descriptions of the first species of Pelecotominae and larva of Ripidiinae (Coleoptera), Zool. J. Linn. Soc.Lond., 188, 412-433, https://doi.org/10.1093/zoolinnean/zlz062, 2020.

Bezděk, J.: A review of Palaearctic Scelolyperus (Coleoptera: Chrysomelidae: Galerucinae), with description of $S$. perreus sp. nov. from Turkey, Ann. Zool., 65, 21-39, https://doi.org/10.3161/00034541ANZ2015.65.1.003, 2015.

Bogri, A., Solodovnikov, A., and Żyła, D.: Baltic amber impact on historical biogeography and palaeoclimate research: Oriental rove beetle Dysanabatium found in the Eocene of Europe (Coleoptera, Staphylinidae, Paederinae), Pap. Palaeontol., 4, 433-452, https://doi.org/10.1002/spp2.1113, 2018.

Brunke, J. A., Żyła, D., Yamamoto, S., and Solodovnikov, A.: Baltic amber Staphylinini (Coleoptera: Staphylinidae: Staphylininae): a rove beetle fauna on the eve of our modern climate, Zool. J. Linn. Soc.-Lond., 187, 166-197, https://doi.org/10.1093/zoolinnean/zlz021, 2019.

Bukejs, A. and Alekseev, V. I.: Description of the second fossil Baltic amber species of Monotomidae (Coleoptera: Cucujoidea), Zootaxa, 3946, 445-450, 2015a.

Bukejs, A. and Alekseev, V. I.: First record of Microscapha LeConte from Baltic amber with description of new species and list of fossil Melandryidae (Coleoptera: Tenebrionoidea), Zootaxa, 4012, 351-360, https://doi.org/10.11646/zootaxa.4012.2.5, 2015 b.

Bukejs, A. and Bezděk, J.: Calomicrus eocenicus sp. nov. (Coleoptera: Chrysomelidae: Galerucinae) from Baltic amber, Baltic Journal of Coleopterology, 14, 73-75, 2014.

Bukejs, A. and Chamorro, M. L.: Two new fossil species of Cryptocephalus Geoffroy (Coleoptera: Chrysomelidae) from Baltic and Dominican amber, P. Entomol. Soc. Wash., 117, 116-125, https://doi.org/10.4289/0013-8797.117.2.116, 2015.

Bukejs, A. and Kairišs, K.: Calomicrus eocenicus Bukejs et Bezděk: P3300.139 [RSM], male, volume rendering of the habitus, TIB, https://doi.org/10.5446/45963, 2020a.

Bukejs, A. and Kairišs, K.: Calomicrus eocenicus Bukejs et Bezděk: P3300.139 [RSM], male, volume rendering of the pterothorax without legs, TIB, https://doi.org/10.5446/45964, 2020b.

Bukejs, A. and Kairišs, K.: Calomicrus eocenicus Bukejs et Bezděk: P3300.139 [RSM], volume rendering of the aedeagus, TIB, https://doi.org/10.5446/45965, 2020c.
Bukejs, A. and Konstantinov, A. S.: New genus of flea beetle (Coleoptera: Chrysomelidae: Galerucinae: Alticini) from the Upper Eocene Baltic amber, Insecta Mundi, 030, 1-5, 2013.

Bukejs, A., Biondi, M., and Alekseev, V. I.: Sucinolivolia torpidaa new genus and species of flea-beetles (Coleoptera: Chrysomelidae: Galerucinae) from Baltic amber, Zootaxa, 4058, 119-126, https://doi.org/10.11646/zootaxa.4058.1.7, 2015.

Bukejs, A., Biondi, M., and Alekseev, V. I.: New records and species of Crepidodera Chevrolat (Coleoptera: Chrysomelidae) in Eocene European amber, with a brief review of described fossil beetles from Bitterfeld amber, Zootaxa, 4193, 390-400, https://doi.org/10.11646/zootaxa.4193.2.13, 2016.

Bukejs, A., Alekseev, V. I., and Pollock, D. A.: Waidelotinae, a new subfamily of Pyrochroidae (Coleoptera: Tenebrionoidea) from Baltic amber of the Sambian peninsula and the interpretation of Sambian amber stratigraphy, age and location, Zootaxa, 4664, 261-273, https://doi.org/10.11646/zootaxa.4664.2.8, 2019.

Cai, C. and Huang, D.: Sexual dimorphism in mid-Cretaceous silvanid beetles from northern Myanmar (Coleoptera, Silvanidae, Brontinae), Palaeoentomology, 002, 289-296, https://doi.org/10.11646/palaeoentomology.2.3.14, 2019.

Crowson, R. A.: The biology of the Coleoptera, Academic press, London, 1981.

Dillwin, L. W.: Memoranda relating to coleopterous insects found in the neighbourhood of Swansea, W. C. Murray and D. Rees, Swansea, 75 pp., 1829.

Engel, M. S.: A monograph of the Baltic amber bees and evolution of the Apoidea (Hymenoptera), B. Am. Mus. Nat. Hist., 259, 1-192, https://doi.org/10.1206/00030090(2001)259<0001:AMOTBA>2.0.CO;2, 2001.

Fanti, F. and Sontag, E.: A new fossil soldier beetle (Coleoptera: Cantharidae: Malthininae) from Baltic amber, Zootaxa, 4629, 583-588, https://doi.org/10.11646/zootaxa.4629.4.6, 2019.

Gamboa, S. and Ortuño, V. M.: A new fossil species of the genus Coptodera Dejean, 1825 (Coleoptera: Carabidae: Lebiinae) from Baltic amber, Zootaxa, 3981, 592-596, https://doi.org/10.11646/zootaxa.3981.4.9, 2015.

Gamboa, S. and Ortuño, V. M.: A new fossil species of the genus Limodromus Motschulsky, 1850 (Coleoptera: Carabidae: Platynini) from Baltic amber with remarks on its death process, Insect Systematics and Evolution, 49, 399-408, https://doi.org/10.1163/1876312X-00002169, 2018.

Gistel, J. N. F. X.: Naturgeschichte des Thierreichs. Für höhere Schulen, Hoffmann'sche Verlags-Buchhandlung, Stuttgart, xvi + $216+4$ pp., 1848.

Gullan, P. J. and Cranston, P. S.: The insects: an outline of entomology, Wiley-Blackwell, Chichester, West Sussex, UK, 2014

Heuss, K.: Zur Taxonomie und Ökologie der Schlammkäfer des Baltischen Bernsteins mit einem Gattungsschluessel und der Beschreibung einer neuen Art (Coleoptera: Scirtidae), Entomologische Zeitschrift, 118, 131-134, 2008.

Hieke, F. and Pietrzeniuk, E.: Die Bernstein-Käfer des Museums zur Naturkunde, Berlin (Insecta, Coleoptera), Mitteilungen aus dem Museum für Naturkunde in Berlin, 60, 297-326, 1984.

Hope, F. W.: Observations on succinic insects, T. Roy. Ent. Soc. London, 1, 133-147, 1836.

Jałoszyński, P., Brunke, A. J., Yamamoto, S., and Takahashi, Y.: Evolution of Mastigitae: Mesozoic and Cenozoic fossils crucial for reclassification of extant tribes (Coleoptera: Staphylin- 
idae: Scydmaeninae), Zool. J. Linn. Soc.-Lond., 184, 623-652, https://doi.org/10.1093/zoolinnean/zly010, 2018.

Jiang, R., Liu, Z., and Wang, S.: Fossil evidence for sexual dimorphism in Monotomidae beetles from midCretaceous Burmese amber, Cretaceous Research, 102, 7-11, https://doi.org/10.1016/j.cretres.2019.05.008, 2019.

Kazantsev, S. V.: New taxa of Baltic amber soldier beetles (Insecta: Coleoptera: Cantharidae) with synonymic and taxonomic notes, Russian Entomological Journal, 22, 283-293, 2013.

Kazantsev, S. V.: Protolycus gedaniensis gen. et sp. nov., the first Baltic amber representative of Lycini (Coleoptera: Lycidae: Lycinae), Palaeoentomology, 002, 327-332, https://doi.org/10.11646/palaeoentomology.2.4.5, 2019.

Kirejtshuk, A. G.: A revision of the genus Cupes Fabricius, 1801 from Baltic amber and some notes on taxonomy and composition of the family Cupedidae (Coleoptera, Archostemata), Mitteilungen der Bayerischen Staatssammlung fur Palaontologie und Historische Geologie, 89, 55-84, 2005.

Klausnitzer, B.: Wunderwelt der Käfer, Spectrum, Heidelberg, 2002.

Klausnitzer, B.: Neue Arten der Familie Scirtidae (Coleoptera) aus Baltischem Bernstein (Teil 3) (172. Beitrag zur Kenntnis der Scirtidae), Linzer biologische Beitrage, 44/1, 313-318, 2012.

Klebs, R.: Über Bernsteineinschlüsse in allgemeinen und die Coleopteren meiner Bernsteinsammlung, Schriften der Physikalisch-ökonomischen Gesellschaft zu Königsberg i. Pr, 51, 217-242, 1910.

Kuśka, A. and Kupryjanowicz, J.: Soldier beetles (Coleoptera: Cantharidae) from Baltic amber, Polskie Pismo Entomologiczne, 74, 309-316, 2005.

Lambert, J. B., Santiago-Blay, J. A., Wu, Y., and Levy, A. J.: Examination of amber and related materials by NMR spectroscopy, Magn. Reson. Chem., 53, 2-8, https://doi.org/10.1002/mrc.4121, 2015.

Latreille, P. A.: Histoire Naturelle, Générale et Particuliere des Crustacés, des Insectes. Tome III, F. Dufart, Paris, xii + 13-467 pp., 1802.

Liu, Z., Ślipiński, A., Wang, B., and Pang, H.: The oldest Silvanid beetles from the Upper Cretaceous Burmese amber (Coleoptera, Silvanidae, Brontinae), Cretaceous Research, 98, 18, https://doi.org/10.1016/j.cretres.2019.02.002, 2019.

Lyubarsky, G. Y. and Perkovsky, E. E.: New genus Microticus from Upper Cretaceous of Taymyr (Coleoptera: Cryptophagidae), oldest silken fungus beetle with sexually dimorphic tarsal formula, Russian Entomological Journal, 24, 61-66, 2015.

Mohamedsaid, M. S. and Furth, D. G.: Secondary Sexual Characteristics in the Galerucinae (Sensu Stricto) (Coleoptera: Chrysomelidae), International Scholarly Research Network, Zoology, 2011, 328670, https://doi.org/10.5402/2011/328670, 2011.

Nabozhenko, M., Bukejs, A., and Telnov, D.: Gonialaenini, a new tribe of Lagriinae (Coleoptera: Tenebrionidae) from Eocene Baltic Amber, Zootaxa, 4565, 253-260, https://doi.org/10.11646/zootaxa.4565.2.9, 2019a.

Nabozhenko, M., Chigray, I., and Bukejs, A.: Taxonomic notes on the Eocene Helopini, and a review of the genus Isomira Mulsant, 1856 from Baltic amber (Coleoptera: Tenebrionidae), Insect Syst. Evol., 1-15, https://doi.org/10.1163/1876312X-00002302, 2019b.
Nabozhenko, M. V., Kairišs, K., and Bukejs, A.: The oldest fossil darkling beetle of the genus Neomida Latreille, 1829 (Coleoptera: Tenebrionidae) from Eocene Baltic amber examined with X-ray microtomography, Zootaxa, 4768, 435-442, https://doi.org/10.11646/zootaxa.4768.3.10, 2020.

Nadein, K. S. and Perkovsky, E. E.: A new tribe of Galerucinae leaf beetle (Insecta: Coleoptera: Chrysomelidae) from the Upper Cretaceous Taimyr amber, Cretaceous Research, 84, 97-106, https://doi.org/10.1016/j.cretres.2017.10.023, 2018.

Nadein, K. S., Perkovsky, E. E., and Moseyko, A. G.: New late Eocene Chrysomelidae (Insecta: Coleoptera) from Baltic, Rovno and Danish ambers, Pap. Palaeontol., 2, 117-137, https://doi.org/10.11646/zootaxa.4457.2.5, 2015.

Parisi, F. and Fanti, F.: On the first Silis Charpentier, 1825 from Baltic amber (Coleoptera, Cantharidae), Foss. Rec., 22, 119-123, https://doi.org/10.5194/fr-22-119-2019, 2019.

Perreau, M.: Description of a new genus and two new species of Leiodidae (Coleoptera) from Baltic amber using phase contrast synchrotron X-ray microtomography, Zootaxa, 3455, 8188, 2012.

Perreau, M. and Perkovsky E. E.: Further description of Catops nathani Perkovsky 2001 from late Eocene Baltic amber (Coleoptera: Leiodidae: Cholevinae: Cholevini) using phase contrast synchrotron X-ray microtomography, Annales de la Société entomologique de France (N.S.), 50, 414-417, https://doi.org/10.1080/00379271.2014.984957, 2014.

Perreau, M. and Tafforeau, P.: Virtual dissection using phasecontrast X-ray synchrotron microtomography: reducing the gap between fossils and extant species, Syst. Entomol., 36, 573-580, https://doi.org/10.1111/j.1365-3113.2011.00573.x, 2011.

Poinar, G. O.: Life in amber, Stanford University Press, Stanford, California, 368 pp., 1992.

Prado, L. R.: Review on the use of sexually dimorphic characters in the taxonomy of Diabroticites (Galerucinae, Luperini, Diabroticina), ZooKeys, 332, 33-54, https://doi.org/10.3897/zookeys.332.4931, 2013.

Reike, H.-P., Bukejs, A., Arlt, T., Kardjilov, N., and Manke, I.: Phase-contrast synchrotron microtomography reveals internal morphology of a new fossil species of the Corticariasylvicola-group (Coleoptera: Latridiidae), Zootaxa, 4242, 578590, https://doi.org/10.11646/zootaxa.4242.3.9, 2017.

Reike, H.-P., Alekseev V. I., Gröhn, C., Arlt, T., and Manke, I.: First extinct species of the genus Holoparamecus (Coleoptera: Merophysiidae: Holoparamecinae) from Eocene amber deposits, Studies and Reports, Taxonomical Series, 16, 241-255, 2020.

Ritzkowski, S.: K-Ar-Altersbestimmungen der bernsteinführenden Sedimente des Samlandes (Paläogen, Bezirk Kaliningrad), Metalla (Sonderheft), 66, 19-23, 1997.

Sadowski, E.-M., Schmidt, A. R., Seyfullah, L. J., and Kunzmann, L.: Conifers of the "Baltic amber forest" and their palaeoecological significance, Stapfia, 106, 1-73, 2017.

Santiago-Blay, J. A., Poinar, G. O., and Craig, P. R.: Dominican and Mexican amber chrysomelids, with descriptions of two new species, in: Chrysomelidae Biology, Volume 1: The Classification, Phylogeny and Genetics, edited by: Jolivet, P. H. A. and Cox, M. L., SPB Academic Publishing, Amsterdam, 413-424, 1996.

Schmidt, J.: On the Eocene age of Limodromus Motschulsky, 1850, with description of L. hoffeinsorum sp. n. from Baltic Am- 
ber (Coleoptera: Carabidae: Platynini), Zootaxa, 3974, 573-581, https://doi.org/10.11646/zootaxa.3974.4.8, 2015.

Schmidt, J. and Michalik, P.: The ground beetle genus Bembidion Latreille in Baltic amber: review of preserved specimens and first 3D reconstruction of endophallic structures using X-ray microscopy (Coleoptera, Carabidae, Bembidiini), ZooKeys, 662, 101-126, https://doi.org/10.3897/zookeys.662.12124, 2017.

Schmidt, J., Belousov, I., and Michalik, P.: X-ray microscopy reveals endophallic structures in a new species of the ground beetle genus Trechus Clairville, 1806 from Baltic amber (Coleoptera: Carabidae: Trechini), ZooKeys, 614, 113-127, https://doi.org/10.3897/zookeys.614.9283, 2016.

Schmidt, J., Göpel, T., and Will, K.: Description of the first flightless platynine ground beetle preserved in Baltic amber (Coleoptera: Carabidae), Zootaxa, 4318, 110-122, https://doi.org/10.11646/zootaxa.4318.1.4, 2017.

Schmidt, J., Scholz, S., and Kavanaugh, D. H.: Unexpected findings in the Eocene Baltic amber forests: ground beetle fossils of the tribe Nebriini (Coleoptera: Carabidae), Zootaxa, 4701, 350-370, https://doi.org/10.11646/zootaxa.4701.4.2, 2019.

Shavrin, A. V. and Yamamoto, Sh.: Unexpected palaeodiversity of omaliine rove beetles in Eocene Baltic amber (Coleoptera, Staphylinidae, Omaliinae), ZooKeys, 863, 35-83, https://doi.org/10.3897/zookeys.863.34662, 2019.

Spahr, U.: Systematischer Katalog der Bernstein- und Kopal-Käfer (Coleoptera), Stuttgarter Beiträge zur Naturkunde (Ser. B), 80, 1-107, 1981.

Telnov, D. and Bukejs, A.: Catalogue and composition of fossil Anthicidae and Ischaliidae (Insecta: Coleoptera), Palaeontol. Electron., 22.1.18A, 1-27, https://doi.org/10.26879/885, 2019.
Telnov, D., Bukejs, A., and Merkl, O.: Description of a new fossil Statira Lepeletier et Audinet-Serville, 1828 (Coleoptera: Tenebrionidae: Lagriinae) from Baltic amber, Zootaxa, 4683, 508514, https://doi.org/10.11646/zootaxa.4683.4.2, 2019.

Turkin, N. I.: Preliminary results of microscopic research of tangential wood imprints in Baltic amber, Metalla (Sonderheft), 66, 55-56, 1997.

Vitali, F.: Taxonomic, biological and evolutionistic notes on the Spondylidinae included in Baltic amber (Coleoptera Cerambycidae), Entomapeiron Paleoentomology, 1, 29-44, 2006.

Vitali, F.: Procleomenes gouverneuri sp. n. (Coleoptera: Cerambycidae) from Baltic amber: the first fossil member of the tribe Sestyrini Lacordaire, 1869, Baltic Journal of Coleopterology, 18, 33-38, 2018.

Wagner, T.: Present status of a taxonomic revision of Afrotropical Monolepta and related groups (Galerucinae), in: Special topics in leaf beetle biology, edited by: Furth, D. G., Proceedings of the Fifth International Symposium on the Chrysomelidae, 25-27 August 2000, Iguassu Falls, Brazil, XXI International Congress of Entomology, Pensoft, Sofia, 133-146, 2003.

Wickham, H. F.: Fossil Coleoptera from Florissant, with descriptions of several new species, B. Am. Mus. Nat. Hist., 30, 53-69, 1911.

Wolfe, A. P., Tappert, R., Muehlenbachs, K., Boudreau, M., McKellar, R. C., Basinger, J. F., and Garrett, A.: A new proposal concerning the botanical origin of Baltic amber, P. Roy. Soc. B-Biol. Sci., 276, 3403-3412, https://doi.org/10.1098/rspb.2009.0806, 2009. 